\title{
The Associations of Ward Head Direction and Incentive with Nurse Performance at Arun LNG Hospital, Lhokseumawe, Aceh
}

\author{
Irwadi, Zulfendri, Destanul Aulia \\ Masters Program in Public Health, Universitas Sumatera Utara
}

\begin{abstract}
Background: The current transformation in the hospital care industry demands greater coordination of care across providers and across settings so as to improve quality care, improve outcomes, and reduce spending. Nurses contribute to the transformative changes by being a fully contributing member of the inter-professional team. It requires an enhanced set of knowledge, skills, attitudes, and performance among nurses around wellness and population care with a renewed focus on patient-centered care, care coordination, data analytics, and quality improvement. This study aimed to analyze the associations of ward head direction and incentive with nurse performance at Arun LNG Hospital, Lhokseumawe, Aceh.

Subjects and Method: This was a cross-sectional study carried out at Arun LNG Hospital, Lhokseumawe, Aceh. A sample of 74 nurses was selected for this study by exhaustive sampling. The dependent variable was nurse performance. The independent variables were ward head direction and incentive. The data were collected by questionnaire and analyzed by a multiple logistic regression.
\end{abstract}

Results: Nurse performance improved with high motivation $(\mathrm{OR}=11.12 ; 95 \% \mathrm{CI}=2.66$ to 46.49 ; $\mathrm{p}=0.001)$, explicit ward head direction $(\mathrm{OR}=4.37 ; 95 \% \mathrm{CI}=1.05$ to $18.17 ; \mathrm{p}=0.043)$, and existence of incentive $(\mathrm{OR}=5.84 ; 95 \% \mathrm{CI}=1.30$ to $26.17 ; \mathrm{p}=0.021)$.

Conclusion: Improved nurse performance is associated with explicit ward head direction and existence of incentive.

Keywords: nurse performance, ward head direction, incentive

\section{Correspondence:}

Irwadi. Masters program in Public Health, Universitas Sumatera Utara, Medan, North Sumatera. Email: wadieadi655@gmail.com. Mobile: 08126922595.

\section{BACKGROUND}

Increased productivity and performance of nurses are very important in an effort to improve the efficiency of health services. The performance of a nurse is strongly influenced by knowledge, skills, and motivation as well as the conditions of a supportive work environment. It is the ability of a leader in a hospital to influence workers to love their work, not solely to take orders from superiors, but moved his heart to complete his task with his own awareness.

Based on Law No. 36 of 2009 concerning health article 23, it is explained that health personnel are authorized to provide health services in accordance with their expertise. Then in article 24, it is explained that health personnel must meet health service standards, especially nurses in providing nursing care.

Improving the performance of qualified nurses is one of the important things to note because without a qualified nurse, how sophisticated the existing system is, the vision, mission and goals of the hospital, it will be difficult to achieve. The formation of nurse performance is a reflection of the quality of nursing provided (Suriana, 2014).

The individual performance can be influenced by individual, psychological, and 
organizational factors. The individual variables include abilities, skills, family background and demographics, organizational variables include resources, leadership, rewards, work structure and design, and psychological variables include perception, attitude, personality, learning and motivation. The three groups of variables affect work groups which ultimately affect employee performance (Gibson, 2011). Nurse performances can be measured based on nursing care competencies consisting of assessment, diagnosis, planning, implementation and evaluation (PPNI, 2005).

The leadership of the head department which is task-oriented for nurses usually has the target of carrying out the task, an organized work plan and evaluation of the work that has been achieved by the nurse and this situation is also supported by the maturity level of nurses who really need clear and firm direction specific to the head of the room so there are clear duties and responsibilities. The leadership of the head of the department that is oriented to nurses can usually meet nurse satisfaction with a low level of moderate maturity, the creation of a conducive work environment, active participation, feeling nurtured, supported, guided, and feeling part of the hospital so that it can cause the nurse's motives to work while increasing quality of work (Sari, 2009). Nurse-oriented leadership needs to be supported by providing compensation to optimize the performance of nurses in hospitals.

Giving compensation is one of the efforts to improve the quality of the performance of nurses and also to meet the needs of nurses. Nurses will work harder and show more spirit according to hospital expectations, if the hospital pays attention to it and fulfill the needs of nurses, both material needs such as salaries, incentives, bonuses and non-material needs such as awards (Zenah, 2014).

PT. Arun LNG Lhokseumawe hospital located in the Plaju Complex Street of PT. Arun Batuphat City of Lhokseumawe is managed by the Enterprise of the Lhokseumawe Development Area (PDPL) starting in January 2016. According to the nursing committee, it was reported that in PT. Arun LNG Lhokseumawe, the number of inpatient visits was 6,220 and outpatient services were 38,874 visits in 2015 and experienced an increase in inpatient visits to 8,978 visits (30.7\%) and a decrease in outpatient visits 35,723 in 2016 (8,8\%). (Arun LNG Hospital, 2017)

The results of interviews with 10 nurses showed that nurses still complained about the leader, the head of department. Some of the heads of departments at PT Arun LNG Lhokseumawe hospital were complained by the nurses because they were not able to become exemplary nurses or exemplary nurses, such as late attendance that made nurses the executor does not hold daily meetings before providing nursing services. It is less assertive to impose sanctions for executing nurses who are late for work, the results of nurse performance have not been evaluated such as completeness of documentation, supervision is not carried out continuously, suggestions submitted to the head of the department in making changes less valued, nurses are rarely involved in taking policy, and give less impetus to improve the performance of implementing nurses.

Based on the above phenomenon, it can be seen that the factors that affect the low performance of nurses at PT. Arun LNG Lhokseumawe, among others, was the leadership of the head of the room in carrying out the functions and tasks that were not yet continuous. The head of the room has not been able to provide direction 
and supervision continuously and less effort to improve ability through guidance and short training and motivating the nurse because nurses were prioritized in improving skills for themselves.

The purpose of this study was to analyze the effect of motivation, leadership of the head of the room, and compensation for the nurse performance at PT Arum LNG Lhokseumawe Hospital.

\section{SUBJECTS AND METHOD}

This study was a cross sectional study. The study was conducted at Arun LNG hospital, Lhokseumawe, Aceh, from February to June 2018. A total of 74 nurses were selected by exhaustive sampling. The dependent variable was nurse performance. The independent variables were motivation, head direction, and incentives. The data were collected by using questionnaire and analyzed by a multiple logistic regression.

\section{RESULTS
1. Frequency Distribution of Study Variables}

Table 1 shows frequency distribution of study variables. Table 1 shows that as many as $44.4 \%$ nurses had good head direction. All nurses received incentive monthly. As many as $27.0 \%$ nurses received the incentive from $\mathrm{Rp} 350,000$ to $\mathrm{Rp} 600,000$ and 73.0\% nurse received incentive from $\mathrm{Rp}$ 150,000 to Rp 350,000.

Table 1. The Frequency Distribution

\begin{tabular}{lcc}
\hline \multicolumn{1}{c}{ Variables } & n & \% \\
\hline Motivation & & \\
\hline Good & 26 & 35.1 \\
Poor & 48 & 64.9 \\
Direction & & \\
Good & 29 & 39.2 \\
Poor & 45 & 60.8 \\
Incentive (Rp) & & \\
350,000- 600,000 & 20 & 27.0 \\
150,000- 350,000 & 54 & 73.0 \\
\hline
\end{tabular}

\section{The Results of Multiple Logistic Regression Analysis}

Table 2 showed the results of a multiple logistic regression. Table 2 showed that high motivation $(\mathrm{OR}=11.12 ; 95 \% \mathrm{CI}=2.66$ to $46.49 ; \mathrm{p}=0.001$ ), positive direction $(\mathrm{OR}=4.37 ; 95 \% \mathrm{CI}=1.05$ to $18.17 ; \mathrm{p}=$ o.043), and adequate incentives ( $\mathrm{OR}=5.84$; $95 \% \mathrm{CI}=1.30$ to $26.17 ; \mathrm{p}=0.021$ ) improved nurse performance.

Table 2.The results of multivariate logistic regression analysis

\begin{tabular}{lcccc}
\hline \multirow{2}{*}{ Independent variables } & \multirow{2}{*}{ OR } & \multicolumn{2}{c}{$\mathbf{9 5 \%}$ CI } & \multirow{2}{*}{$\mathbf{~}$} \\
\cline { 3 - 4 } & & Lower limit & Upper limit & \\
\hline Motivation & 11.12 & 2.66 & 46.49 & 0.001 \\
Direction & 4.37 & 1.05 & 18.17 & 0.043 \\
Incentive & 5.84 & 1.30 & 26.17 & 0.021 \\
Constant & 0.02 & & & $<0.001$ \\
\hline
\end{tabular}

\section{DISCUSSIONS}

\section{The relationship between motiva- tion and nurses performance}

The result of this study showed that motivation affected the nurse performance. High motivation improved nurse performance. Work motivation was an influential condition to generate, direct, and maintain the behaviors which related to the work environment (Usman, 2013). The result of this study was in line with Aduo-Adjei (2016), who stated that motivation was an intrinsic factor that affected a nurse's performance. 


\section{The relationship between head direction and nurse performance}

The result of this study showed thatthe head of the room in providing direction could improve nurse performance. Rashed et al. (2015) showed that nurse leaders have specific responsibilities to their staff and organizations to supervise and provide direction to nurses so they can perform their work optimally.

\section{The relationship between incentive and nurse performance}

The result of this study showed that incentive affected the nurse performance. High incentives increased nurse performance. Incentives were a component of indirect financial compensation, which included all benefits who were not covered by direct compensation in the form of salaries, wages, and commissions (Dharmawan, 2011). The result of this study was in line with Rudasingwa and Uwizeye (2017), who stated that incentives were related to nurse performance. The low number of incentives and sometimes experiencing delays decrease the nurse's motivation, thus reducing the nurse's performance.

Similar result also showed by Aninanya et al. (2016), who stated that incentives could increase the motivation of health personnel in carrying out their work, which has an impact on their performance.

\section{REFERENCES}

Aduo-Adjei K,Emmanuel O, Forster OM (2016).The Impact of Motivation on the Work Performance of Health Workers (Korle Bu Teaching Hospital): Evidence from Ghana. Hospital Practices and Research. 1(2):47-52.

Aninanya GA, Howard N,Williams JE, Apam B, Prytherch H, Loukanova S, Kamara EK, Otupiri E (2016).Can performance-based incentives improve motivation of nurses and mid- wives in primary facilities in northern Ghana? A quasi-experimental study. Glob Health Action.9: 32404.doi: 10.3402/gha.v9.32404

Dharmawan Y(2011). Pengaruh Kompensasi dan Lingkungan Kerja Non Fisik terhadap Disiplin dan Kinerja Karyawan Hotel Nikki Denpasar. Tesis. Universitas Udayana Denpasar. Bali.

Gibson J, James I, John D (2011). Organization behavior. Boston: Mc GrawHill Higher Education.

Rashed SAE, Torky MAMA, Morsey SM (2015). Performance of head nurses management functions and its effect on nurses' productivity at Assiut University Hospital. IOSR Journal of Nursing and Health Science. 4(5): 3849.

Rudasingwa M, Uwizeye MR (2017). Physicians' and nurses' attitudes towards performance-based financial incentives in Burundi: a qualitative study in the province of Gitega. Glob Health Action. 10(1): 1270813. doi: 10.108o/16549716.2017.1270813.

Rumah Sakit PT. Arun LNG (2017). Profil Rumah Sakit PT. Arun LNG Lhokseumawe.

Sari MT (2009). Hubungan Budaya Organisasi dan Kepemimpinan Kepala Ruangan dengan Kinerja Perawat Pelaksana.Tesis.Universitas Indonesia.

Suriana, 2014.Analisis Kinerja Perawat (Studi Ruang Rawat Inap di Rumah Sakit Umum Daerah Tanjung Uban Provinsi Kepulauan Riau). Fakultas Ilmu Sosial dan Politik. Universitas Maritim Raja Ali Haji (Gibson, 2011).

Usman H (2013). Manajemen Teori, Praktik, dan Riset Pendidikan. Edisi. Keempat. Jakarta Timur: Bumi Aksara 